\title{
A survey on how different factors impact entrepreneurs' success in food industry
}

\author{
Ghahraman Abdoli $^{\mathrm{a}}$, Hedayat Tajik ${ }^{\mathrm{b}}$, Ehsan Ghasemi ${ }^{\mathrm{b}}$ and Behrooz Jamali ${ }^{\mathrm{b}}$
}

Faculty of Economics, University of Tehran, Tehran, Iran

Entrepreneurship Management University of Tehran, Tehran, Iran

AR T I C L I N F O AB S T R A T

Article history:

Received March 29, 2012

Received in Revised form

June, 12, 2012

Accepted 25 June 2012

Available online

June 302012

Keywords:

Entrepreneurs' success

Food industry

Job creation

\begin{abstract}
In this paper, we present an empirical study to detect important factors influencing the success of entrepreneurs who were active in food industry in Tehran, Iran. The proposed study selects a sample of 174 people out of 318 entrepreneurs who were involved in this industry and distributed a questionnaire, which consists of two groups of questions among them. The first group of questions is associated with personal characteristics of the survey people and the second group of questions are related to different financial, infrastructure and supply chain management categories. The study defines entrepreneurs' mental desirability of success in terms of 15 different questions and asks them to provide their insights in terms of five Likert based responses. The results of questions are analyzed using Pearson correlation test and the preliminary results indicate that, among personal characteristics, education and age play important roles on the success of a business plan. The other observation is that the easier entrepreneurs can get loans and financial support, the higher abilities to absorb new customers and the higher chance of success for absorbing new financial resources. Distributions of sales, compared with competing products as well as distribution of after sales service for customers are negatively associated with infrastructures. The rate of success in using new technologies and supply chain management are correlated, which means the better supply chain, the better achievement to information technology.
\end{abstract}

\section{Introduction}

These days, entrepreneurs play important role on creating jobs and opportunities in the world and they lead many firms or organizations (Cooper, 1988). Management skill and strong team building capabilities are necessary leadership attributes for successful entrepreneurs. They tend to add more value to world's economy as technology advances and make it easier to create new ideas. Therefore, it is important to learn more about the challenges as well as barriers that entrepreneurs deal with and provide alternative solutions to reduce the burden of challenges.

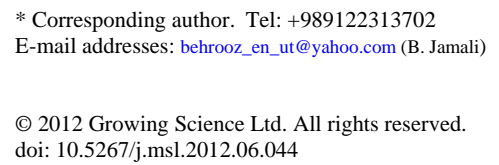


Jo \& Lee (1996) investigated the relationship between an entrepreneur's background and performance in a new venture. They perform a deep investigation on how an entrepreneur's background is associated with the performance of a new venture during the early stages, which has been a subject of different studies in entrepreneurship research. They performed the survey in using the data collected from 48 new start-up firms in Korea and the results of the analysis indicated that the relative profit is higher when an entrepreneur maintains more education and experience in the line of business. On the other hand, the profitability tends to be low when the entrepreneur has only start-up, managerial and high-growth experience without an educational background.

Opportunity recognition, opportunity evaluation and exploitation, resource allocation and resource combination to make new combinations, managerial capabilities, relative autonomy and risk taking propensity, lack of adequate time and resources, ambiguity, ambivalence and high environmental novelty are the most common characteristics in entrepreneurial decision-making atmosphere and process. Entrepreneurial decision-making is a multi-step, multi-characteristic process. It is the result of interaction among expectations of the future, information at hand and the evaluation and estimation of the information (Aldrich \& Zimmer, 1986).

Jo \& Lee (1996) also explained that in the growth of the firm and the positive impact is on growth if an entrepreneur keeps a professional knowledge of the product gained through previous work experience associated with different products. If the entrepreneur has start-up, managerial and highgrowth experience, but does not have a good knowledge of business, this results in a rather negative influence on the growth. The results is consistent with what Taylor (1975) presented.

Cassar (2006) investigated how entrepreneur opportunity expenditures impact the intended future size of new ventures based on a survey of nascent entrepreneurs in the process of starting a venture. They investigated how intended future sales revenue was impacted by entrepreneur current household income, education, and managerial experience. They reported that individuals with higher current household income and greater supervisory experience had higher levels of intended firm size in 5 years time.

Choi et al. (2008) discussed on the performance implications of the timing that entrepreneurs should stop exploring their business opportunities and they must start exploiting them. They specified such time schedule based on optimal-stopping approach. Changes in legitimacy and competition are normally achieved based on how entrepreneurs manage their own knowledge under various degrees of novelty for the business opportunity. These changes, in turn, affect the performance and timing of opportunity exploitation.

Ucbasaran et al. (2009) explained that experienced entrepreneurs in the past identified more opportunities and exploited more innovative opportunities with greater wealth creation potential. Entrepreneurs that had owned more than 4.5 businesses, however, determined fewer opportunities. The nature of prior business ownership experience also described opportunity identification behavior.

A rational decision making process is the combination of enough information, the knowledge regarding the problem, sufficient and reliable alternatives and the comprehensive assessment of the alternatives. Environmental complexities and constant change could result in not fully rational decision-making. As the size and age of organizations and also the number of staff and employees grow, decision making becomes more rational and follows special rules and frameworks. In entrepreneurial, decision-making, the manager's and it's team's individual characteristics play major roles (Simon \& Houghton, 2003).

In a rational decision making process, decision maker should fully consider all the facts and information available, needed time, market situation, competitors, possible losses and gains, should 
be fully considered and contemplated, then the decision could be made. This process usually will not more likely occur in the early years of business (Forbes, 2005).

\section{The proposed study}

We have used the following formula to calculated the minimum number of sample size required, $n=\frac{N \times z_{\alpha / 2}^{2} \times p \times q}{\varepsilon^{2} \times(N-1)+z_{\alpha / 2}^{2} \times p \times q}$,

where $N$ is the population size, $p=1-q$ represents the yes/no categories, $z_{\alpha / 2}$ is CDF of normal distribution and finally $\varepsilon$ is the error term. Since we have $p=0.5, z_{\alpha / 2}=1.96$ and $N=318$, the number of sample size is calculated as $n=174$.

\subsection{Personal characteristics of the surveyed people}

In this section we present details of personal characterics of the participants in our survey. First we present details of the participant who took part in our survey. From 173 people who filled our survey, 19 people were from 30 to 39 years old, 39 were between 40 and 40, 57 people were from 50 to 59 years old and 58 people were aged 60 to 60 . Fig. 1 shows the frequencies of these people.

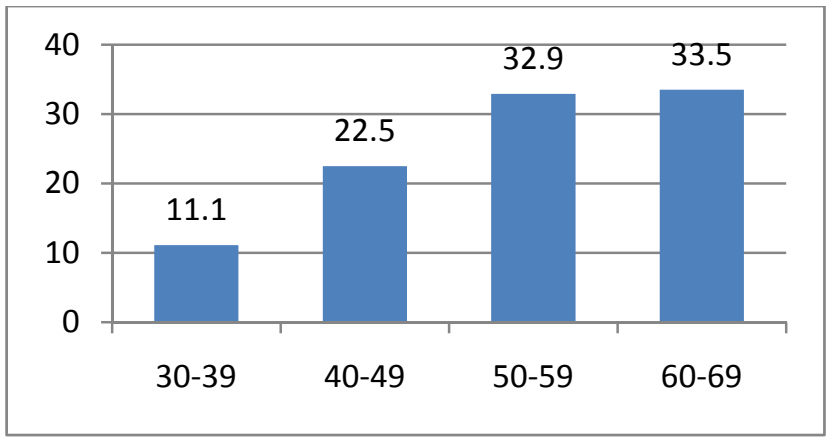

Fig. 1. Frequency of the participants' age in terms of percentage

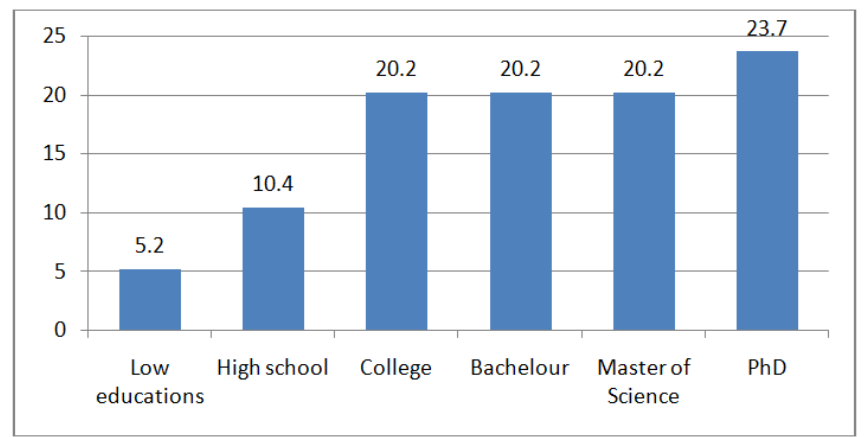

Fig. 2. Frequency of the educational backgrounds of participants in terms of percentage

From the Fig. 1, it is clear that entrepreneurs who particiapted in our survey were mostly senior. The other characteristics of the entrepreneurs who took part in our survey is associated with their educational backgrounds. Fig. 2 shows their relative job experinces. According to Fig 2, we can observe that entrepreneurs are mostly educated and they maintain good background of knowledge.

\subsection{Independent variables}

There are three independent variable in this study, which includes financial resources, supply chain and infrastructure. The first group is associated with financial, the second groups is related to environmental infrastructure and the thrid group is related to supply chain system. In fact, supply chain management includes all stages involved from production to final customer delivary stage. In other words, we need to have a good support from the suppliers who are responsible to provide raw materials to final stage where final goods or services are delivered to customers.

The proposed model of this paper uses Pearson correlation analysis to study the relationships of different independent variables on some dependent variables. The first independent variable is associated on how easy it was to get a loan $\left(x_{1}\right)$, the second variable is on low interest loans 
government gives to entrepreneurs $\left(x_{2}\right)$, the third variable is related to required utilities to start up a business unit $\left(x_{3}\right)$, the fourth variable is associated with the availability of required facilities to maintain food products $\left(x_{4}\right)$, the fifth variable is about how much entrepreneurs succeeded to deliver their products to dealers directly $\left(x_{5}\right)$ and finally, the last variable was associated with the obtaining the necessary raw materials $\left(x_{6}\right)$. As we can see, the firs two variables are associated with financial affairs, the second two variables are related to infrstructures and the last two variables are linked to supply chain management. In addition, we consider four personal characteristcs including age, education, relative experinece on food industry and entrepreneurs' personal experiences.

\subsection{Dependent variable}

In this study, food industry entrepreneurs' mental function is the dependent variable and the questionnaire contains 15 perspectives summarized in Table 1 as follows,

\section{Table 1}

Different perspectives for measuring success

\begin{tabular}{|c|c|c|c|}
\hline Var. & Perspective & Var. & Perspective \\
\hline$y_{1}$ & $\begin{array}{l}\text { Desirability of distributing quality products } \\
\text { offered to customers }\end{array}$ & $y_{9}$ & $\begin{array}{l}\text { Distribution of success rate in attracting } \\
\text { skilled staff to suit your needs }\end{array}$ \\
\hline$y_{2}$ & $\begin{array}{l}\text { Distribution of after-sales service for } \\
\text { customers }\end{array}$ & $y_{10}$ & The rate of success in using new technologies \\
\hline$y_{3}$ & $\begin{array}{l}\text { Distribution of success rate in attracting new } \\
\text { customers }\end{array}$ & $y_{11}$ & $\begin{array}{l}\text { Distribution of success rate in placing the } \\
\text { development of new products }\end{array}$ \\
\hline$y_{4}$ & $\begin{array}{l}\text { Distribution of success rate in new products to } \\
\text { market }\end{array}$ & $y_{12}$ & $\begin{array}{l}\text { The rate of success in using technology in all } \\
\text { matters }\end{array}$ \\
\hline$y_{5}$ & $\begin{array}{l}\text { The success rate in providing timely } \\
\text { distribution of goods and services to customers } \\
\text { and improving the production cycle }\end{array}$ & $y_{13}$ & $\begin{array}{l}\text { Distribution of success rate in attracting } \\
\text { capital and financial resources }\end{array}$ \\
\hline$y_{6}$ & $\begin{array}{l}\text { The success rate in avoiding duplication and } \\
\text { distribution companies to reduce costs and } \\
\text { enhance the ability of the company products }\end{array}$ & $y_{14}$ & $\begin{array}{l}\text { Distribution of success rate in obtaining an } \\
\text { appropriate share of the market }\end{array}$ \\
\hline$y_{7}$ & $\begin{array}{l}\text { The success rate of participation in employee } \\
\text { satisfaction by providing appropriate services } \\
\text { to their }\end{array}$ & $y_{15}$ & $\begin{array}{l}\text { Distribution of sales, compared with } \\
\text { competing products }\end{array}$ \\
\hline$y_{8}$ & $\begin{array}{l}\text { Distribution of success rate in providing } \\
\text { necessary training to employees }\end{array}$ & & \\
\hline
\end{tabular}

\section{Data analysis and results}

In order to analyze the data, we first study correlations between mental function and other independent variables. Table 2 shows details of our survey. As we can observe from the results of Table 2, there are only few meaningful correlations between independent and dependent variables when the level of significance is defined as five percent and they are shown with bold characters.

Table 3 summarizes the meaningful effects and As we can observe education plays an important role on attracting new customers and success in providing new products to market. In other words, people with higher educational backgrounds were capable of absorbing new customers and providing new products for their exsiting customers as well. 
Table 2

Pearson correlations between $y_{1}-y_{15}$ and independet variables Age, Education, Family experience,

\begin{tabular}{|c|c|c|c|c|c|c|c|c|c|c|}
\hline $\mathrm{Y}$ & Age & Education & $\begin{array}{c}\text { Family } \\
\text { experience }\end{array}$ & $\begin{array}{c}\text { Work } \\
\text { experience }\end{array}$ & $x_{1}$ & $X_{2}$ & $X_{3}$ & $X_{4}$ & $X_{5}$ & $x_{6}$ \\
\hline $\mathrm{y}_{1}$ & 0.055 & 0.175 & 0.027 & 0.027 & -0.173 & 0.025 & -0.064 & 0.101 & 0.064 & 0.119 \\
\hline P-valu & 0.475 & 0.021 & 0.721 & 0.721 & 0.023 & 0.743 & 0.364 & 0.136 & 0.405 & 0.120 \\
\hline $\mathrm{y}_{2}$ & 0.060 & -0.329 & 0.048 & 0.048 & -0.211 & 0.154 & -0.249 & -0.293 & -0.043 & -0.216 \\
\hline P-value & 0.430 & 0.000 & 0.531 & 0.531 & 0.005 & 0.043 & 0.001 & 0.000 & 0.573 & 0.004 \\
\hline $\mathrm{y}_{3}$ & 0.001 & 0.161 & 0.075 & 0.075 & 0.165 & -0.010 & -0.062 & -0.088 & -0.036 & 0.007 \\
\hline P-value & 0.991 & 0.035 & 0.326 & 0.326 & 0.030 & 0.901 & 0.0419 & 0.249 & 0.636 & 0.922 \\
\hline $\mathrm{y}_{4}$ & 0.069 & 0.444 & 0.010 & 0.010 & 0.053 & 0.024 & -0.034 & -0.165 & -0.115 & -0.112 \\
\hline P-value & 0.368 & 0.000 & 0.892 & 0.892 & 0.468 & 0.751 & 0.662 & 0.030 & 0.132 & 0.141 \\
\hline $\mathrm{y}_{5}$ & 0.072 & -0.092 & -0.004 & -0.004 & 0.049 & 0.133 & -0.119 & -0.056 & -0.017 & -0.068 \\
\hline P-value & 0.347 & 0.229 & 0.950 & 0.954 & 0.524 & 0.080 & 0.120 & 0.464 & 0.821 & 0.371 \\
\hline $\mathrm{y}_{6}$ & 0.004 & -0.162 & -0.042 & -0.042 & -0.065 & -0.105 & 0.014 & 0.032 & 0.031 & 0.000 \\
\hline P-value & 0.959 & 0.033 & 0.579 & 0.579 & 0.395 & 0.169 & 0.850 & 0.676 & 0.862 & 0.995 \\
\hline $\mathrm{y}_{7}$ & -0.045 & -0.156 & 0.028 & 0.028 & 0.003 & 0.026 & -0.052 & -0.112 & 0.000 & -0.093 \\
\hline P-value & 0.560 & 0.040 & 0.718 & 0.718 & 0.968 & 0.734 & 0.498 & 0.142 & 0.997 & 0.222 \\
\hline $\mathrm{y}_{8}$ & 0.054 & 0.031 & 0.031 & 0.038 & -0.136 & 0.066 & 0.014 & 0.029 & -0.069 & -0.059 \\
\hline $\begin{array}{l}\text { y8 } \\
\text { P-value }\end{array}$ & 0.480 & 0.688 & 0.615 & 0.615 & 0.075 & 0.387 & 0.852 & 0.704 & 0.364 & 0.442 \\
\hline $\mathrm{y}_{9}$ & 0.007 & -0.061 & -0.005 & -0.005 & -0.077 & -0.060 & 0.086 & 0.069 & 0.013 & 0.065 \\
\hline P-value & 0.929 & 0.423 & 0.947 & 0.947 & 0.314 & 0.434 & 0.260 & 0.370 & 0.870 & 0.398 \\
\hline $\mathrm{y}_{10}$ & 0.090 & -0.104 & 0.000 & 0.000 & -0.081 & -0.295 & -0.241 & 0.090 & 0.434 & 0.325 \\
\hline $\mathrm{P}$-value & 0.239 & 0.172 & 0.999 & 0.999 & 0.287 & 0.000 & 0.001 & 0.239 & 0.000 & 0.000 \\
\hline $\mathrm{y}_{11}$ & -0.144 & -0.293 & 0.003 & 0.003 & 0.129 & 0.063 & 0.172 & -0.084 & -0.235 & -0.217 \\
\hline P-value & 0.059 & 0.000 & 0.964 & 0.964 & 0.090 & 0.408 & 0.024 & 0.270 & 0.002 & 0.004 \\
\hline $\mathrm{y}_{12}$ & 0.261 & 0.159 & -0.028 & -0.028 & -0.057 & 0.039 & 0.223 & -0.057 & -0.392 & 0.047 \\
\hline $\mathrm{P}$-value & 0.001 & 0.037 & 0.715 & 0.715 & 0.459 & 0.608 & 0.003 & 0.456 & 0.000 & 0.539 \\
\hline $\mathrm{y}_{13}$ & 0.171 & 0.183 & 0.056 & 0.056 & 0.381 & 0.071 & 0.218 & 0.078 & -0.224 & -0.105 \\
\hline P-value & 0.025 & 0.016 & 0.468 & 0.468 & 0.000 & 0.352 & 0.004 & 0.307 & 0.003 & 0.169 \\
\hline $\mathrm{y}_{14}$ & 0.135 & 0.012 & 0.011 & 0.011 & -0.025 & -0.044 & -0.513 & -0.041 & -0.161 & 0.026 \\
\hline P-value & 0.076 & 0.874 & 0.888 & 0.888 & 0.747 & 0.563 & 0.000 & 0.596 & 0.035 & 0.732 \\
\hline $\mathrm{y}_{15}$ & -0.041 & -0.127 & 0.009 & 0.009 & -0.245 & 0.579 & -0.408 & -0.504 & -0.302 & -0.422 \\
\hline P-value & 0.591 & 0.095 & 0.910 & 0.910 & 0.001 & 0.000 & 0.000 & 0.000 & 0.000 & 0.000 \\
\hline
\end{tabular}

In addition, people with higher educations and higher ages were also able to attract new financial resources more easily and implement recent advances of technology faster.

Table 3

The summary of important factors

\begin{tabular}{|c|c|c|c|c|c|c|c|c|c|}
\hline \multirow[b]{2}{*}{$\mathrm{Y}$} & & \multicolumn{2}{|c|}{ Personalcharacteristics } & \multicolumn{2}{|c|}{ Financial } & \multicolumn{2}{|c|}{ Infrastructure } & \multicolumn{2}{|c|}{ Supply chain } \\
\hline & & Age & Education & $X_{1}$ & $X_{2}$ & $X_{3}$ & $X_{4}$ & $X_{5}$ & $X_{6}$ \\
\hline $\mathrm{y}_{2}$ & $\begin{array}{l}\text { Distribution of after sales service for } \\
\text { customers }\end{array}$ & & -0.329 & -0.211 & 0.154 & -0.249 & -0.293 & & -0.216 \\
\hline P-value & & & 0.000 & 0.005 & 0.043 & 0.001 & 0.000 & & 0.004 \\
\hline $\mathrm{y}_{3}$ & Th success in attracting new customers & & 0.161 & 0.165 & & & & & \\
\hline P-value & & & 0.035 & 0.030 & & & & & \\
\hline $\mathrm{y}_{4}$ & Success rate in new products in market & & 0.444 & & & & -0.165 & & \\
\hline P-value & & & 0.000 & & & & 0.030 & & \\
\hline $\mathrm{y}_{7}$ & $\begin{array}{l}\text { Success rate of participation in employee } \\
\text { satisfaction by providing appropriate } \\
\text { services to them }\end{array}$ & & -0.156 & & & & & & \\
\hline P-value & & & 0.040 & & & & & & \\
\hline $\mathrm{y}_{10}$ & $\begin{array}{l}\text { The rate of success in using new } \\
\text { technologies }\end{array}$ & & & & -0.295 & -0.241 & & 0.434 & 0.325 \\
\hline P-value & & & & & 0.000 & 0.001 & & 0.000 & 0.000 \\
\hline $\mathrm{y}_{11}$ & $\begin{array}{l}\text { Success rate in placing the development of } \\
\text { new products }\end{array}$ & & -0.293 & & & 0.172 & & -0.235 & -0.217 \\
\hline P-value & & & 0.000 & & & 0.024 & & 0.002 & 0.004 \\
\hline $\mathrm{y}_{12}$ & $\begin{array}{l}\text { Success rate in using technology in all } \\
\text { matters }\end{array}$ & 0.261 & 0.159 & & & 0.223 & & -0.392 & \\
\hline $\mathrm{P}$-value & & 0.001 & 0.037 & & & 0.003 & & 0.000 & \\
\hline $\mathrm{y}_{13}$ & $\begin{array}{l}\text { Success rate in attracting capital and } \\
\text { financial resources }\end{array}$ & 0.171 & 0.183 & 0.381 & & 0.218 & & -0.224 & \\
\hline P-value & & 0.025 & 0.016 & 0.000 & & 0.004 & & 0.003 & \\
\hline $\mathrm{y}_{14}$ & $\begin{array}{l}\text { Success rate in obtaining an appropriate } \\
\text { share of the market }\end{array}$ & & & -0.025 & & -0.513 & & -0.161 & \\
\hline $\mathrm{P}$-value & & & & 0.747 & & 0.000 & & 0.035 & \\
\hline $\mathrm{y}_{15}$ & $\begin{array}{l}\text { Distribution of sales, compared with } \\
\text { competing products }\end{array}$ & & & -0.245 & 0.579 & -0.408 & -0.504 & -0.302 & -0.422 \\
\hline P-value & & & & 0.001 & 0.000 & 0.000 & 0.000 & 0.000 & 0.000 \\
\hline
\end{tabular}


Distribution of sales, compared with competing products as well as distribution of after sales service for customers are negatively associated with infrastructures. In other word, it seems that entrepreneurs mostly believe that many existing big corporations with good infrastructures may not necessarily handle distribution tasks, properly. The rate of success in using new technologies and supply chain management are highly and positively correlated, which means the better supplay chain, the better achievement to information technology. The other observation is that the easier entrepreneurs can get loans and financial support, the higher new customers they could attract and the higher chance of success for absorbing new financial resources.

\section{Conclusion}

In this paper, we have presented a survey among 174 entrepreneurs who were active in food industry in capital city of Iran, Tehran. The study investigated the effects of different factors on the success of these people using a survey questionnaire and distributed a survey among them in Likert scale. The primary purpose of the survey was to detect important factors such as financial affairs including short and long-term loans, good access on infrastructures, having reliable supply chain system, job experience and education background on their success. The results of the survey revealed that education played an important role on attracting new customers and success in providing new products to market. In other words, people with higher educational backgrounds were capable of absorbing new customers and providing new products for their exsiting customers as well. In addition, people with higher educations and higher ages were also able to attract new financial resources more easily and implement recent advances of technology faster. The other observation was that the easier entrepreneurs can get loans and financial support, the higher abilities to absorbe new customers and the higher chance of success for absorbing new financial resources. Distribution of sales, compared with competing products as well as distribution of after sales service for customers are negatively associated with infrastructures. In other word, it seems that entrepreneurs mostly believe that many existing big corporations with good infrastructures may not necessarily handle distribution tasks, properly. The rate of success in using new technologies and supply chain management are highly and positively correlated, which means the better supplay chain, the better achievement to information technology.

\section{References}

Aldrich, H.E., \& Zimmer, C. (1986). Entrepreneurship through social networks. In D.L. Sexton Publishing, 3-23.

Cassar, G. (2006). Entrepreneur opportunity costs and intended venture growth. Journal of Business Venturing, 21(5), 610-632.

Choi, Y.R., Lévesque, M., \& Shepherd, D.A. (2008). When should entrepreneurs expedite or delay opportunity exploitation? Journal of Business Venturing, 23(3), 333-355.

Cooper, A.C, Woo, C. Y., \& Dunkelberg, W.C. (1988). Entrepreneurs' perceived chances for success. Journal of Business venturing, 3(2), 97-108.

Forbes, D.P. (2005). Are some entrepreneurs more over confident than others? Journal of Business Venturing, 20(5), 623-640.

Jo, H., \& Lee, J. (1996).The relationship between an entrepreneur's background and performance in a new venture. Technovation, 16(4), 161-171.

Ucbasaran, D., Westhead, P., \& Wright, M. (2009). The extent and nature of opportunity identification by experienced entrepreneurs. Journal of Business Venturing, 24(2), 99-115.

Simon, M., \& Houghton, S. (2003). The relationship between overconfidence and the introduction of risky products: evidence from a field study. Academy of Management Journal, 46(2), 139- 150.

Taylor (1975). Age and experience as determinants of managerial information processing and decision making performance. Academy of Management Journal, 18(1), 74-81. 